\title{
Religiosity vs. Well-Being Effects on Investor Behavior
}

\author{
Paul-Olivier Klein \\ University of Strasbourg \\ Strasbourg, France \\ Rima Turk \\ International Monetary Fund \\ Washington DC, USA \\ Laurent Weill* \\ EM Strasbourg Business School, University of Strasbourg \\ Strasbourg, France
}

\begin{abstract}
Does religiosity impact the trading of securities in financial markets? We separate two channels that could affect investor behavior, disentangling a religiosity effect from a well-being effect. Our original identification strategy compares the stock market reaction to sukuk and bond issuance during the holy month of Ramadan, allowing for a differentiated stock market reaction to the religious component of a trade. Using the event study methodology, we measure abnormal returns for a sample of 2,140 issuances by 133 issuers in Malaysia over the period 2000-2013. While we find evidence for both channels, sukuk issuance during Ramadan is valued more positively than bond issuance by stock market investors. Further, the positive reaction to sukuk issuance during Ramadan only rewards firms which issue sukuk exclusively. Our findings support the view that religiosity influences the behavior of investors, suggesting that this factor should be taken into account in the analysis of financial markets.
\end{abstract}

JEL Codes: G14, P51.

Keywords: Behavioral finance, Religion, Islamic Finance, Ramadan effect.

* Corresponding author. Institut d'Etudes Politiques, Université de Strasbourg, 47 avenue de la Forêt Noire, 67082 Strasbourg Cedex, France. E-mail : laurent.weill@unistra.fr 


\section{INTRODUCTION}

Religion has long been considered an important factor shaping economic institutions (Stulz and Williamson, 2003), market outcomes (Kumar, Page and Spalt, 2011) and people's economic behavior (Guiso, Sapienza, and Zingales, 2003). Recent work also shows that religiosity exerts an impact on financial conduct, e.g., through the role of moral incentives in the repayment of contractual loans (Baele, Farooq, and Ongena (2014) and short-term facilities (Bursztyn et al., 2015).

The role of religiosity in financial markets-where the majority of traders are professional investors - is more uncertain. The literature suggests that investors are subject to psychological biases when making investment decisions (Daniel, Hirshleifer, and Teoh, 2002; Barberis and Thaler, 2003) and that trading experience reduces but does not eliminate behavioral biases in financial markets (Feng and Seasholes, 2005). However, religious bias in financial markets has not been investigated yet, due to the lack of information on trades that are motivated by religious beliefs and the difficulty to isolate them from other investments.

Our aim in this paper is to determine whether religiosity impacts the trading of securities in financial markets. In countries with both a conventional and an Islamic financial market, listed companies have the choice of issuing conventional bonds or sukuk to meet their large-scale financing needs. Sukuk are alternative modes of financing to conventional bonds that are compliant with the Islamic legal code. The religious content of sukuk makes them rather unique financial instruments to examine how religiosity influences the behavior of stock market investors.

To isolate a potential religious bias of investors in stock markets, we follow a twofold identification strategy. First, we compare the stock market reaction to sukuk issuance during and outside the holy month of Ramadan. This month is characterized by fasting, reading the Qur'an in its entirety, engaging in spirituality by intensifying prayers, and making donations to the needy. Further, the fast-breaking meal at the end of each day often takes place with a large number of family members and as such involves many interactions with fellow believers. Against this background, the month of Ramadan can influence individual views and beliefs by favoring religiosity, including financial decisions. Since Islam has specific prescriptions for financial ethics, Ramadan may thus foster religiosity which, in turn, leads investors to place more value on Islamic instruments.

However, Ramadan can also favor a different reaction from investors due to a well-being effect. This month of fasting can be associated with holidays and thereby generating a positive sentiment around its occurrence. Furthermore, the well-being of individuals may be enhanced during Ramadan because of a daily routine that includes pre-dawn and fast-breaking meals, which are social events combining family and friends (Campante and Yanagizawa-Drott, 2013). 
Hence, our identification strategy should isolate the religious aspect of the Ramadan period from its "well-being" component. To that end, we compare the stock market reaction to sukuk and conventional bond issuance, which are two distinct financial instruments (Cakir and Raei, 2007; Godlewski, Turk-Ariss, and Weill, 2013), during Ramadan. The rationale is that the difference in the market reaction to sukuk and bonds issuance during the Ramadan can be attributed to the religious component of the sukuk instrument, after all relevant financial factors are taken into account. Hence, our identification strategy allows us to isolate the religious from the well-being factors affecting the trade.

To investigate the market impact of religiosity, we use an event study methodology using the Malaysian capital market as empirical fieldwork. Malaysia has by far the largest market for sukuk, gathering $86.8 \%$ of the industry size worldwide (KFUPM, 2016), the majority of which is issued by listed companies. ${ }^{1}$ Moreover, Malaysia has the second deepest bond market in emerging countries relative to its GDP (Tendulkar, 2015). We examine the market reaction to sukuk and bond issuance between 2000 and 2013 by measuring the associated abnormal stock returns of the issuing companies, both during and outside Ramadan. Our main contribution is to isolate the religious component of traders' behavior. Through our identification strategy, we are able to provide evidence for a sizeable impact of religiosity on the stock market.

Our work has important implications for investors by providing information on the influence of religiosity on the behavior of market participants. It also examines the weight of religious aspects in Islamic finance and the ensuing fact that firms may strategically use financial instruments to select investors from a religious angle. Last, it informs on the ability of management to time the market when it comes to fixed income issuance, as the literature has shown that calendar effects can play a significant role in the firm's value.

The remainder of the paper is organized as follows. The next section provides background to our research question. Section 3 discusses the dataset and the methodology. Section 4 contains the results. Section 5 concludes.

\section{BACKGROUND}

Our study is at the intersection of two strands of literature: behavioral biases on financial markets and Islamic finance. We therefore review papers that have addressed both topics.

\section{A. From Behavioral to Religious Biases}

Behavioral finance postulates that people's beliefs challenge the efficiency of financial markets. There is a debate in the literature over the extent to which financial agents act in an irrational way. Building on persistent patterns in stock returns, Daniel, Hirshleifer, and

\footnotetext{
${ }^{1}$ Based on our computations with Bloomberg data, $60 \%$ of corporate sukuk during the period of the study were issued by listed companies.
} 
Subrahmanyam (1998) and Daniel, Hirshleifer, and Subrahmanyam (2001) propose a model that accounts for market inefficiencies stemming from behavioral biases. Opposing this approach, Fama (1998) emphasizes the role of misinterpretations, data-mining, and model errors in the results backing market inefficiency. Subsequent papers fall short of explaining the roots of persistent over or underpricing. For instance, Kothari, Lewellen, and Warner (2006) find evidence supporting market efficiency, whereas Zhang (2006), Kumar (2009) support behavioural biases.

To overcome this deadlock, the literature progressively used more precise proxies for behavioural biases. Coval and Shumway (2005) investigate the behaviour of traders on the Chicago Board of Trade with trading-level data and report that traders recording losses in the morning take higher risk in the afternoon. Feng and Seasholes (2005) also find evidence of a disposition effect, i.e. the reluctance of investor to realize losses and the propensity to realize gains, a result that is however challenged by Ben-David and Hirshleifer (2012). Bailey, Kumar, and $\mathrm{Ng}$ (2011) document that funds investors suffer from important biases and can be described as "Gambler, Smart, Overconfident, Narrow Framer, and Mature".

Overall, the literature documents evidence of behavioural biases in financial markets. Looking for the roots of these biases, the role of culture and ultimately religion are often put forward. However, proxies for the religiosity of investors are usually not directly observable. For instance, Kumar, Page, and Spalt (2011) investigate the impact of religion on investors' behaviour through geography, using the share of Catholics and Protestants in the US states. They do find that investors from states with relatively more Catholics invest more in lotterytype stocks and use more stock-options. However, their approach suffers from identification issues with a controversial geographical proxy, and the fact that religious and cultural effects can hardly be disentangled.

More recent papers address these issues using the framework of Islamic finance. Baele, Farooq, and Ongena (2014) link the religious prescriptions of Islamic finance with the rate of loan defaults in Pakistan. Comparing Islamic and conventional loans and using more precise geographical proxies, such as the political vote and the number of Islamic schools in neighbourhoods, they observe that religiosity reduces the default rate. Bursztyn et al. (2015) also conduct a field experiment on Islamic credit cards and show that religious incentives in the reminder of payments exert a strong impact on the refunding rate on short-term facilities.

Whereas there is nascent evidence in the literature of a religious bias in the repayment of retail loans, the role of religiosity on traders' behaviour is so far entangled with the influence of wellbeing. Several papers examined the returns of stock markets during Ramadan.

Seyyed, Abraham, and Al-Hajji (2005) study the volatility of stock returns in the Saudi Arabian stock market during 1985-2000 and find that market volatility is lower during Ramadan. Bialkowski, Etebari and Wiesniewski (2012) investigate stock returns during Ramadan for 14 
countries with a predominant Muslim population over the period 1989-2007. They observe higher stock returns and reduced volatility during Ramadan in comparison with the rest of the year for their whole sample. The country-by-country analysis shows that 11 out of 14 countries have higher returns during Ramadan, including Malaysia. Bialkowski et al. (2013) also find that the performance of institutional fund managers in Turkey is substantially higher during Ramadan than in other months.

Turk-Ariss, Rezvanian, and Mehdian (2011) extend the analysis by testing for a month-of-the year and day-of-the-week effect on stock market returns in Gulf Cooperation Council countries over the period 1994-2008. In addition to Ramadan, they also consider the possible influence of months of the Gregorian calendar on stock returns. Moreover, they test for a Friday-type effect by considering potential anomalies for Wednesday in these countries, because Wednesday is the last day before the weekend on the main market of the region, the Saudi Arabian stock market. As a consequence, a Wednesday effect is not related to Islamic calendar anomalies but rather to investor optimism at the end of the work week. They find support for a Wednesday effect, which is less pronounced during the month of Ramadan. They also observe lower volatility of stock market returns during Ramadan.

Al-Khazali (2014) analyzes the Ramadan effect for the stock returns of 15 Muslim countries using a stochastic dominance approach over the period 1995-2012. He documents a positive Ramadan effect on stock returns in most countries, although its magnitude has been diminished with the financial crisis.

Halari et al. (2015) examine Islamic monthly anomalies on the Pakistani stock market, finding greater stock returns during four months including Ramadan but which are nonetheless not significant for most firms. However, they also document significantly lower stock volatility during two months including Ramadan, concluding that Ramadan is the best month for an investor to make a risk-adjusted profit.

Hence, the literature concurs that returns on stock markets are different during the month of Ramadan. However, these anomalies cannot necessarily be linked to religion but may derive from the well-being of investors, similar to the findings for Western countries where calendar anomalies are well-documented and which have nothing to deal with religiosity. ${ }^{2}$ Henceforth, we offer an identification strategy to extract any religious component in the stock market using both the Ramadan period as well as financial instruments in Islamic and conventional finance.

\footnotetext{
${ }^{2}$ For instance, January and end-of-the-week effects. See Gultekin and Gultekin (1983), Jaffe and Westerfield (1985) and Ariel (1987) for seminal references.
} 


\section{B. Islamic Finance and Sukuk}

Islamic finance can be defined as finance that conforms to Islamic law (sharia), which imposes several requirements on financial contracts. The main precept is the prohibition of interest in all financial transactions which, however, does not imply that capital is not rewarded. Rather, interest is replaced by profit-and-loss sharing, where both parties in a financial transaction share the returns from an investment. Another aspect of Islamic finance is the prohibition of activities considered as sinful by sharia, including investment in alcohol, pork, cigarettes, military, and entertainment (International Monetary Fund, 2015; Hussain, Shahmoradi, and Turk-Ariss, 2015).

There has been a strong expansion of Islamic financial activities in the recent years. According to TheCityUK (2015), Islamic financial assets have reached \$2.2 trillion end 2015, and have tripled since 2007. While the vast majority (80\%) of these assets is accounted for by Islamic banks, sukuk represent about $15 \%$. Sukuk are alternative modes of financing to conventional bonds that are compliant with sharia. They are investment certificates issued by sovereigns and corporations that combine similarities and differences with conventional bonds.

Like bonds, sukuk have a maturity date and their holders expect to receive a regular stream of income including capital refunding at the end of the investment horizon. These similarities can explain why some scholars consider that sukuk are not different instruments than conventional bonds (e.g., Miller, Challoner and Atta, 2007, and Wilson, 2008).

Unlike bonds, however, the value of sukuk may be either based on the creditworthiness of the issuer or rely solely on the value of the underlying project. Sukuk certificates correspond ownership rights in tangible assets, usufruct, or services of revenue-generating issuers, with the underlying asset being shari'a-compliant. In a typical sukuk structure, a special purpose vehicle (SPV) buys the assets underlying the firm's investment project by raising funds from investors who receive ownership certificates. These certificates entitle the holders a regular stream of cash-flows and capital redemption at maturity. The project is managed by the issuer who can buy the underlying assets back. The aim of this structure is to transfer ownership of

the underlying assets to the investors, thereby rendering the sukuk in conformity with the sharia.

Sukuk can be structured as debt-based instruments or partnership contracts. Debt-based instruments such as ijara (rental/lease agreement) and murabaha (cost-plus sale) do not contain stricto sensu interest but they pay a predetermined rate of return to investors. Musharaka and mudaraba are partnership contracts in which the provider of funds and the issuing company share profits based on pre-agreed ratios. Losses are commensurate to the contribution to the partnership in the case of the musharaka and otherwise entirely supported by the investors in the case of the mudaraba. 
The large expansion of sukuk in the last decade raises questions about the impact of sukuk issuance for the issuing firm. In particular, the influence of sukuk financing on firm valuation is important to appraise the expansion of this nascent type of financing, as a more positive stock market reaction to sukuk issuance favors the choice of this financing instrument relative to bonds. Two studies provide evidence on the comparative stock market reaction to the announcements of both sukuk and conventional bonds.

Godlewski, Turk-Ariss, and Weill (2013) find that, in Malaysia, the stock market is neutral to the announcement of conventional bonds but investors react negatively to the announcement of sukuk, notwithstanding excess demand from Islamic financial institutions that makes it easier to sell these instruments. The negative implications of sukuk issues are attributed to possible adverse selection considerations, as borrowers with the lowest return expectations may favor the issuance of profit-and-loss sharing sukuk structures over conventional interestbased bonds.

Using a sample of sukuk issues across eight countries, Godlewski, Turk-Ariss, and Weill (2016) take the analysis a step further by examining whether the sukuk type and characteristics of shari'a scholars (advisors who certify shari'a compliance of sukuk) influence the stock market reaction to issuances. They find that both the choice of sukuk structure and scholars hired for its certification influence the stock market reaction to issuances.

Thus, existing papers provide evidence of a different stock market reaction to sukuk and bond issuance, as well as a role for sukuk characteristics. This conclusion opens the possibility that sukuk and bond issuances are impacted differently by some features. It therefore appears of interest to investigate whether the religiosity of investors can exert a role in the reaction to sukuk issuance.

\section{EMPIRICAL STRATEGY}

\section{A. Data}

We use data on bonds and sukuk issued by listed companies in Malaysia between 2000 and 2013. Malaysia was successful in developing both bond and sukuk markets, with the sukuk outstanding amount representing $54 \%$ of the total bonds outstanding in $2015 .^{3}$ It is important to stress that the sukuk market in Malaysia is characterized by an overwhelming amount of debt-based sukuk: murabaha and ijara sukuk account respectively for $66 \%$ and $7 \%$ of total sukuk in 2015, whereas the shares of musharaka and wakala sukuk are $12 \%$ and $10 \%$, respectively. The remaining $5 \%$ is a combination of different contracts.

\footnotetext{
${ }^{3}$ Information provided by the Securities Commission website: http://www.sc.com.my/data-statistics/islamiccapital-market-statistics. Last view 17/05/2016.
} 
We retrieve data come from the Bloomberg Professional Server, considering only public straight debt issuances and removing hybrid securities. We obtain a preliminary sample of 5,706 issuances, of which 3,000 are sukuk issuances. Our final sample size is determined by data availability and methodology considerations. First, we only keep issuances for which the issuer has minimum financial records, dropping issuers who lack information on total assets, book value of debt, sales, and earnings for the year of the issuance. For the market analysis, we need stock pricing over 171 days before and 21 days after security issuance, so that we remove issuers without enough stock market data. To prevent any overlapping between events, we also remove issuances from the same issuer that occur within 10 working days. Last, since we need to distinguish clearly between bond and sukuk issuances as part of our identification strategy, we remove issuances by the same firm of both types of securities that occur on the same day.

Our final sample includes 2,140 issuances by 133 corporate issuers. More precisely, 83 listed Malaysian firms issued sukuk and 79 issued bonds, with some firms issuing both types of securities. We identify issuances occurring during the month of Ramadan, by collecting the dates of Ramadan in Malaysia since 2000, relying on Malaysian official records. ${ }^{4}$

Table 1 describes the sample distribution across the Ramadan period, years, and sectors of economic activity. We observe 96 bond issues and 111 sukuk issues during Ramadan, compared with 935 bond issues and 998 sukuk issues, respectively, for the full sample. Hence, the proportion of issues during Ramadan is proportional to the length of this period for bonds (40 days out of 365), whereas there is proportionally slightly more issues of sukuk during Ramadan than during the rest of the year.

The number of issuances has steadily increased since the year 2000, but this trend was reversed with the global financial crisis, and the market has not returned to the pre-crisis level of issuances reached in 2007. The majority of securities issuances are by companies in the industrial sector followed by banks, but firms engaged in the consumer segment are also significant players in the market.

Table 2 reports descriptive statistics for the characteristics of issuances and issuers. We keep all debt maturities in our sample, resulting in an important dispersion in the sample. We observe that there are significant differences between bonds and sukuk, suggesting that these two instruments may be different. Bond issuances are larger, on average, than sukuk issuances and they pay slightly lower coupon rate over a shorter maturity period. However, there is no statistical difference in the size of both types of issuers who appear to be of similar size. Bond issuers have more leverage and higher profitability than sukuk issuers. In the multivariate analysis, we take into account the different features of issuers and issues.

\footnotetext{
${ }^{4}$ The identification of the Ramadan period rests on the lunar calendar and it starts by approximately 10 days earlier each year (http://www.islam.gov.my/en/node/26745).
} 


\section{B. Methodology}

To investigate the impact of Ramadan on sukuk, we perform an event study on the stock market reaction around sukuk and bond issuance. We adopt the standard event study methodology as described by MacKinlay (1997) to compute abnormal returns (AR) around the issue date.

We first estimate expected returns from a market model, such as:

$$
R_{n, t}=\alpha_{i}+\beta_{n} \cdot R_{m, t}+\varepsilon_{n, t}
$$

$R_{n, t}$ is the daily return of the share price of the company $n$ the day $t$, and is computed as $R_{n, t}=\frac{P_{n, t}-P_{n, t-1}}{P_{n, t-1}}$, where $P_{n, t}$ is the closing price. $R_{m, t}$ is the market return and $\varepsilon_{n, t}$ is the abnormal return over the estimation period, with $E\left[\varepsilon_{n, t}\right]=0$ and $\operatorname{Var}\left[\varepsilon_{n, t}\right]=\sigma_{i}^{2}$.

We collect data on four main indices which may be used to calculate market returns in Malaysia. ${ }^{5}$ We choose the index with the highest $\mathrm{R}^{2}$, namely the FTSE Bursa Malaysia Emas Index (FBMEMAS), which is a weighted index of large and mid-cap companies.

We use an estimation period of -171 days to -21 working days before the sukuk or bond issuance to prevent any impact or contamination from the current issuance. This also allows us to systematically compute expected returns outside the Ramadan period (which lasts 29 days on average).

Next, we compute abnormal returns as follows:

$$
A R_{n, t}=R_{n, t}-E\left[R_{n, t}\right]
$$

Where the expected return $E\left[R_{n, t}\right]$ is calculated from the market model in the main analysis as:

$$
E\left[R_{n, t}\right]=\widehat{\alpha_{n}}+\widehat{\beta_{n}} \cdot R_{m, t}
$$

We allow the market to anticipate the event and to take one more day to fully integrate its impact. Hence, we consider the day before and after the event too, corresponding to a [-1,1] window.

We then compute Cumulative Abnormal Returns (CARs) as:

$$
C A R_{n}\left(\tau_{1}, \tau_{2}\right)=\sum_{t=\tau_{1}}^{\tau_{2}} A R_{n, t}
$$

\footnotetext{
${ }^{5}$ Namely, the MSCI Malaysia Index (MSDLMAF), the FTSE Bursa Malaysia Top 100 Index (FBM100), the FTSE Bursa Malaysia KLCI Index (FBMKLCI) and the FTSE Bursa Malaysia Emas Index (FBMEMAS). A popular index is also the FTSE Bursa Malaysia Emas Sharia Index (FBMS) including shar'ia-compliant firms only. However we do not consider this last index since we want a religious-neutral index for both sukuk and bond issuers.
} 
With $\tau_{1}$ the first day of the window and $\tau_{2}$ the last day. We also calculate the average $C A R$ across companies as:

$$
\overline{C A R}\left(\tau_{1}, \tau_{2}\right)=\frac{1}{N} \sum_{n=1}^{N} C A R_{n}\left(\tau_{1}, \tau_{2}\right)
$$

To assess the significance of $A R \mathrm{~s}$ and $C A R \mathrm{~s}$ we perform three complementary tests. First, we conduct a cross-sectional t-test $\left(t^{C S}\right)$ which considers only the variance within the event windows:

$$
t_{\left(\tau_{1}, \tau_{2}\right)}^{C S}=\frac{\overline{C A R}\left(\tau_{1}, \tau_{2}\right)}{\sqrt{\left[\frac{1}{N-1} \sum_{i=1}^{N}\left(\overline{C A R}_{i}\left(\tau_{1}, \tau_{2}\right)-\overline{C A R}\left(\tau_{1}, \tau_{2}\right)\right)\right]^{2}}}
$$

The cross-sectional statistic is most suited to investigate calendar anomalies. Notably, Bialkowski et al. (2012) use it to find that volatility is lower during Ramadan. The reason is that the cross-sectional t-test takes into account a potential change in the variance of returns between the estimation and the observation period.

As an alternative statistic, we compute the Boehmer, Masumeci, and Poulsen (1991) statistic $\left(t^{B M P}\right)$, which considers the variance of stock returns both outside and within the observation period. To this end, we first calculate the variance of $A R \mathrm{~s}$ over the estimation period $\left(\sigma_{i, \varepsilon}^{2} e\right)$. Then, each $C A R$ is standardized by the variance of the estimation period, resulting in standardized cumulative abnormal returns $(S C A R)$ as follows:

$$
\operatorname{SCAR}_{i}\left(\tau_{1}, \tau_{2}\right)=\frac{\operatorname{CAR}_{i}\left(\tau_{1}, \tau_{2}\right)}{\sqrt{\left(\tau_{2}-\tau_{1}+1\right) \cdot \sigma_{i, \varepsilon}^{2}}}
$$

Next, the $t^{B M P}$ statistic is obtained by dividing the cross-sectional average SCAR by its crosssectional standard deviation during the event period:

$$
t_{\left(\tau_{1}, \tau_{2}\right)}^{B M P}=\frac{\frac{1}{N} \sum_{i=1}^{N} \operatorname{SCAR}_{i}\left(\tau_{1}, \tau_{2}\right)}{\sqrt{\left[\frac{1}{N-1} \sum_{i=1}^{N}\left(S C A R_{i}\left(\tau_{1}, \tau_{2}\right)-\frac{1}{N} \sum_{i=1}^{N} S C A R_{i}\left(\tau_{1}, \tau_{2}\right)\right)\right]^{2}}}
$$

Last, CARs are often characterized by an important dispersion with extreme reactions. We perform a sign test over the percentage of negative CARs to be sure that those reactions do not drive our findings.

In a second part, we aim to isolate the impact of Ramadan on stock market reaction to issuances. We perform OLS regressions using CARs over the [-1,1] event window as the dependent variable. Our key explanatory variable is Ramadan, which is a dummy variable set to one if the issue takes place during Ramadan and zero otherwise. We also interact this variable with the dummy variable $S u k u k$, which is equal to one if the issuance is a Sukuk and zero otherwise. Hence, we are able to isolate the effects of Ramadan on the stock market reaction. 
We capture the religiosity effect in regressions that include Sukuk, Ramadan, and Sukuk $\times$ Ramadan as right-hand side variables. The coefficient on Sukuk depicts the general differential stock market reaction to sukuk issuance relative to bond issuance. A significant coefficient for Ramadan would imply that this month has an influence of the stock market reaction following issuances of bonds only. Indeed, if Sukuk is equal to 1, the effect of issuing a Sukuk during Ramadan is depicted by the interaction term Sukuk $\times$ Ramadan. If the issue is a bond, the interaction term is equal to zero and the variable Ramadan illustrates the effect of issuing a bond during Ramadan. Last, the interaction Sukuk $\times$ Ramadan corresponds to the specific stock market reaction following sukuk issuance relative to bond issuance during Ramadan. In other words the coefficient on Sukuk $\times$ Ramadan considers the impact of the religiosity of investors on the sukuk, which is the key dimension that we investigate in this paper. The total impact of issuing a sukuk during Ramadan on the stock market is the sum of the coefficients on Sukuk, Ramadan, and for Sukuk×Ramadan.

To control for other determinants of CARs, we also include issuance and issuer characteristics. We select two issuance characteristics: the amount of issuance in USD measured in $\log$ (Amount), and the maturity of the issuance in years (Maturity). We also consider five issuer characteristics: issuer size defined by the log of sales (Size), Market-to-Book, Leverage as the ratio of total debt to total assets, Current Ratio as the ratio of current assets to current liabilities, and Profitability measured as the ratio of earnings before interest and taxes (Ebitda) to total assets. We include year fixed effects and industry fixed effects.

\section{Results}

We first display the univariate results, followed by the multivariate estimations. We then provide additional investigation by considering separately unique and multiple issuers before concluding with robustness checks.

\section{A. Abnormal Returns during Ramadan}

Table 3 displays univariate results. We report summary statistics on $C A R$ s around security issuances of sukuk and bonds, also distinguishing among issuances taking place during or outside Ramadan.

We first point out the absence of a Ramadan effect as a whole for all security issuances. Our univariate results do not provide evidence for a significantly different stock market reaction to security issuance during the month of Ramadan relative to other months of the year.

We also find that sukuk issuance generates a negative stock market reaction that is significant using the cross-sectional statistic when the issuance takes place outside Ramadan. However, the market reaction is insignificant when the issuance occurs during Ramadan. This first result is of interest because it tends to show a Ramadan effect for sukuk. This calendar effect may have several explanations at this point. First, issues during Ramadan may be of higher quality 
for shareholders. This argument calls for a multivariate analysis controlling for the characteristics of issues and issuers. Second, a Ramadan effect may also stem from behavioral biases. This period may be more pleasant for shareholders because it corresponds to a period of celebration, with numerous public holidays and social interactions. Alternatively, a greater religiosity during that month may contribute to improve the perception of issuers using financial instruments that are compliant with sharia. So far, we cannot disentangle these effects and need to dig deeper in our investigations.

Next, we observe that CARs following bond issuance are significantly negative for issuances taking place during Ramadan, while they are not significant for issuances outside Ramadan. This significance observed using the cross-sectional statistic may yield three explanations. It could be that issues are of poorer quality during Ramadan, which is a period with fewer trading days. Alternatively, this period may be more stressful for shareholders, as people may be more irascible, have frequent headaches, and suffer from sleep deprivation due to night rest interruption for a snack before dawn when the fasting begins (Leiper and Molla, 2003). Last, greater religiosity during that month may contribute to deteriorating the perception of issuers of financial instruments that are noncompliant with sharia.

Therefore, the univariate analysis shows evidence of a Ramadan effect for bond and sukuk issuances in opposite directions. The stock market reaction deteriorates for bond issuance, but it improves following sukuk issuance as the occurrence of Ramadan cancels the negative impact of sukuk issuance during other months. The fact that the effect of Ramadan is opposite for bonds and sukuk adds some weight to the religious interpretation of financial market reaction. A priori, there is no financial reason explaining why managers choose to issue bond of poor quality and sukuk of high quality during Ramadan. Similarly, there is no reason explaining a difference in the well-being effect between the two securities during Ramadan. So far, these findings suggest that religiosity during Ramadan bears an influence that leads investors to favour sukuk issues and dismiss bond issues. We explore this hypothesis further in a multivariate analysis framework.

\section{B. Multivariate Estimations}

Table 4 reports multivariate results for the Ramadan effect. We perform several regressions of CARs. We first include the single effect of Sukuk without considering the Ramadan period, controlling for a set of variables (Column 1). We then investigate the Ramadan effect as a whole by including Ramadan and the same control variables (Column 2). The remaining estimations consider together the three dummy variables Sukuk, Ramadan, and Sukuk $\times$ Ramadan to provide information on a Ramadan effect for sukuk issuance, and testing for three different specifications to examine how the set of control variables can influence the results. Column 3 includes no control variable, column 4 considers only issuance variables, and column 5 has all issuance and issuer controls. 
In the first column, we find no significant coefficient for Sukuk, meaning that no significant difference in stock market reaction is observed following sukuk issuance relative to bond issuance. This result differs from the conclusion of a negative stock market reaction found by Godlewski, Turk-Ariss and Weill (2013), which could be explained by the use of more recent data in our sample going until 2013 while theirs stopped in 2009. The development of sukuk markets may have influenced their perception by stock market investors.

When testing for the presence of a Ramadan effect for all security issuances in column 2, we do not find a significant coefficient for Ramadan either. Hence we confirm the univariate results of the absence of a Ramadan effect for security issuances in general.

We then turn to the key part of the estimations by analyzing the Ramadan effect for sukuk issuances in the last three columns of the table. We observe that the coefficient on Ramadan is negative and significant when considering the effect of sukuk. At the same time, the coefficient on the interaction term Sukuk $\times$ Ramadan is positive and significant.

As we include the dummy variable for sukuk issuance and the interaction term between sukuk issuance and Ramadan issuance, the coefficient for Ramadan informs on the impact of a bond issuance during Ramadan. Hence, the negative coefficient for Ramadan means that bond issuance during the month of Ramadan generates a negative stock market reaction relative to bond issuances taking place during the rest of the year.

The positive and significant coefficient for Sukuk $\times$ Ramadan informs on the difference in the market reaction to bond and sukuk issued during Ramadan. We find that sukuk issuance during Ramadan is valued more positively than bond issuance by stock market investors. Since we control for issue and issuer characteristics and consider the overall sukuk effect with the dummy variable Sukuk, the difference between bond and sukuk during Ramadan can be affected to the sole effect of religiosity on investor reaction during that period.

This result is a key finding because it shows that some part of traders' behavior is determined by religious considerations. The religious component of the shareholders' reaction (Sukuk $\times$ Ramadan) is also significant from an economic standpoint, since it represents an abnormal return of $1.6 \%$, which is substantial for the issuing firm. Using the mean capitalization of companies issuing sukuk during Ramadan, the religious component of the trade represents USD 9.876 million of stock value in abnormal return due to religiosity. In a similar fashion, issuing sukuk during Ramadan instead of outside Ramadan would generate an additional USD 11.576 million of stock value. ${ }^{6}$ Therefore, not only has religiosity an impact on traders' behavior, but its impact is also economically significant.

\footnotetext{
${ }^{6}$ For comparison, Malaysia had a market capitalization of roughly USD 500bn in 2013 (World Bank Data Base) http://data.worldbank.org/indicator/CM.MKT.LCAP.CD/countries.
} 
What is the overall impact of issuing sukuk during Ramadan? The F-test of the sum of the coefficients for Sukuk, Ramadan and Sukuk $\times$ Ramadan is not significant. In other words, to issue sukuk during Ramadan does not have a significant impact on stock market reaction. Sukuk seem to benefit from shareholders' religiosity, which outweighs the negative effect observed for bonds during Ramadan. This is confirmed by the sum of the coefficients on Ramadan and Sukuk $\times$ Ramadan, which is positive and significant: adding only the religious part of the reaction to the general reaction to sukuk issues yields a positive reaction.

How to explain this negative effect for bonds issues occurring during Ramadan? The coefficient Ramadan only represents the reaction to bonds during Ramadan and does not compare this effect with sukuk issues. Hence, two competitive hypotheses arise as this effect may be attributed to both a well-being effect and a religious effect. First, shareholders may be stressed by the Ramadan period, reducing their well-being and leading to a negative reaction. Second, shareholders may sanction firms which choose to issue bonds, i.e. to use a security which contradicts with the sharia during a holy period. Since we cannot disentangle this religious and well-being effect for bonds, we allow for the possibility that the two effects exert a role on shareholders' reaction.

In a nutshell, bonds and sukuk generate a different reaction during Ramadan. Shareholders react negatively to bonds during Ramadan, whereas they do not have any reaction to sukuk in general. As for the significant difference in reaction between bond and sukuk during the Ramadan, it can be attributed to shareholders' religiosity. Traders value the religious component of sukuk with a sizeable abnormal return, but they may punish bond issuers for the issuance of interest-based securities.

\section{Unique vs. Multiple Issuers}

When considering potential reward from issuing religion-based securities and punishment from dealing with interest-based debt securities, it is of interest to explore what happens to firms that issue solely sukuk or bonds compared with those that tap both markets. In line with the reward/punishment interpretation, the reaction of stock market investors can be influenced by the usual behavior of issuers. The reward should be higher for firms that commit to the sukuk market solely. Conversely, firms that usually tap both markets may be not impacted by the religiosity of shareholders. The reason is that the expectations of investors are not the same for both situations. Investors expect a sukuk-only issuing firm to commit to the sukuk market and they may reward it for its commitment, unlike for firms that usually tap both markets. To investigate this hypothesis, we distinguish between unique issuers, or firms that have only issued one type of securities until the concerned issue, and multiple issuers, i.e. firms that have issued both types of securities in the past.

Table 5 displays the estimations considering separately single issuers and multiple issuers. For each category of issuers, we provide results with three alternative sets of explanatory variables: 
the three key variables (Sukuk, Ramadan, Sukuk $\times$ Ramadan) only, the three key variables and the issuance variables, and the three key variables alongside all control variables.

The most striking result is that our main findings of a significantly negative coefficient for Ramadan and a significantly positive coefficient for Sukuk $\times$ Ramadan are maintained for single issuers only. Namely, both these variables are not significant for multiple issuers. In other words, our key finding that bonds and sukuk generate a different reaction during Ramadan only stands for single issuers.

Shareholders react positively to sukuk issuance during Ramadan only if the issuer has loyally issued solely sukuk in the past. Hence, this abnormal return can be directly seen as a reward for firms' commitment to sukuk issuances. In contrast, the estimations show that no specific market reaction occurs for multiple issuers during the month of Ramadan. This result comforts the idea that investors of firms that do not select only one market but tap indifferently both the sukuk and bond markets do not take into account the religious part of the security.

\section{Robustness Checks}

We check the robustness of our results in different tests reported in Table 6, considering the full set of explanatory variables for all tests.

First, we use an alternative event window for cumulative abnormal returns. We redo our estimations by considering one day before the event and the day of the event solely. This corresponds to the $[-1,0]$ event window instead of the $[-1,1]$ event window in the main estimations. We observe that the interaction term Sukuk $\times$ Ramadan is still positive and significant. However Ramadan is no longer significant. Hence, we still observe a significant difference between bond and sukuk during Ramadan, with a positive impact from sukuk and no significant influence from bonds.

Second, we use a modified model instead of the market model. Since our sample is characterized by numerous issuances from few firms, the market model can be misspecified if the estimation period includes too many events (Brown and Warner, 1985). In this case, the expected return is equal to the market return. We find that Ramadan is not significant and that the interaction term $S u k u k \times$ Ramadan is no longer significant albeit remaining positive.

Third, we use an alternative market index to compute stock market returns. We replace the FBMEMAS by the FBM100, which is the market index with the highest $\mathrm{R}^{2}$ after the FBEMAS among the four main indices for which we collected data. Our main findings are maintained. We observe a significantly negative coefficient for Ramadan and a significantly positive coefficient for Sukuk $\times$ Ramadan. Hence the results confirm a negative influence of Ramadan for bond issuances and a positive one for sukuk issuances on stock markets. 
Fourth, we analyze the potential role of the financial crisis on the results. Al-Khazali (2014) observed that the religiosity effect diminished during the financial crisis. Therefore we can question whether the results are influenced by the occurrence of the crisis. To this end, we add a dummy variable Crisis equal to one if the year of the issuance is 2008 or 2009 and zero otherwise, and an interaction term Sukuk $\times$ Ramadan $\times$ Crisis to isolate a potential specific religiosity effect during the crisis. With this alternative specification, our main results still hold with a significantly negative coefficient for Ramadan and a significantly positive coefficient for Sukuk $\times$ Ramadan. At the same time, we observe that the interaction term Sukuk $\times$ Ramadan $\times$ Crisis is not significant. As a result, we conclude that the financial crisis had no impact on the results.

\section{Conclusion}

This paper investigates whether a religious bias may affect trades on a stock market. We develop an identification strategy that isolates the potential religious component of a trade, examining how the month of Ramadan can affect the stock market reaction following the issuance of sukuk relative to conventional bonds. We use an event study methodology for the largest corporate sukuk market in the world in Malaysia, which is also active in conventional bond issuance.

Ramadan provides a framework of prime interest to investigate the behavior of traders because it fosters religiosity with the greater incentives for spirituality during that month. It can consequently exert an influence on the perception of sukuk which are in line with Islamic precepts. However, the Ramadan period may also exert a role on investors' well-being, as it corresponds to a period of festivity. We isolate the religious component during Ramadan by comparing the stock market reaction to sukuk issues to the reaction to conventional bonds issues.

We find support for an impact of religiosity on stock returns. Univariate results show that cumulative abnormal returns are not significant when a sukuk issuance takes place during Ramadan, while they are negative when issuance occurs during the rest of the year. Hence, there is a positive effect of the month of Ramadan on stock returns following a sukuk issue. This result is of particular interest as the abnormal returns during the month of Ramadan are negative for bond issues.

Multivariate results show that Ramadan exerts a positive stock market reaction for sukuk relative to bonds. The difference of reaction between both securities during the month of Ramadan can then be attributed to the religious component of sukuk. In contrast, bond issues during Ramadan are followed by a negative stock reaction. This reaction can either be attributed to a negative well-being effect or a punishment for firms issuing an interest-based security during a holy period. 
To check if the reaction following sukuk or bond issues during Ramadan corresponds to reward or punishment, we conduct further investigation based on the past behavior of the issuing firm. We compare firms which commit to issuing one type of security with firms which issue both instruments, sukuk and bonds. We find that investors react positively to sukuk issuance during Ramadan only if the issuer has loyally issued only sukuk in the past. If the issuer usually taps both markets, there is no religious bias in the reaction of traders to the sukuk issue.

Our findings support the view that religiosity can influence the behavior of investors. This result confirms that psychological biases affect the value of financial securities. Moreover, our identification strategy does not rely on a proxy of religion but directly assesses the religious component of a trade. Second, we also show that one major difference between sukuk and bonds lies in the religious nature of these instruments in the eyes of the investors. As a consequence, managers may be able to strategically choose to issue sukuk or conventional bonds to attract a class of investors. Last, we also show that managers should carefully select the timing of security issuance, as it has a substantial impact on firm value. Depending if they anticipate a reward process from investors or not, they could select the month of Ramadan to issue sukuk or stick to other months to issue bonds.

This paper opens avenues for further research. It represents a first investigation on how calendar anomalies can influence stock market reaction following security issuance. Future work could examine the effect of Islamic religious events for other countries, as well as other calendar anomalies like day-of-the-week or month-of-the-year effect in the Gregorian calendar for security issuances. 
Table 1

Sample Distribution of Issues Across Period, Years, and Industries

The table gives the composition of the sample by day, year, and industry. The sample is composed of 133 issuers with 83 firms having issued Sukuk and 79 firms having issued bonds (some firms issue both securities).

\begin{tabular}{|c|c|c|}
\hline & Bond Issues & Sukuk Issues \\
\hline \multicolumn{3}{|l|}{ Period } \\
\hline During Ramadan & 96 & 111 \\
\hline Outside of Ramadan & 935 & 998 \\
\hline \multicolumn{3}{|l|}{ Years } \\
\hline 2000 & 12 & 3 \\
\hline 2001 & 16 & 4 \\
\hline 2002 & 7 & 5 \\
\hline 2003 & 10 & 12 \\
\hline 2004 & 86 & 92 \\
\hline 2005 & 110 & 131 \\
\hline 2006 & 134 & 213 \\
\hline 2007 & 161 & 215 \\
\hline 2008 & 132 & 186 \\
\hline 2009 & 116 & 80 \\
\hline 2010 & 107 & 56 \\
\hline 2011 & 65 & 63 \\
\hline 2012 & 36 & 34 \\
\hline 2013 & 39 & 15 \\
\hline \multicolumn{3}{|l|}{ Industries } \\
\hline Basic Materials & 74 & 87 \\
\hline Communications & 44 & 22 \\
\hline Consumer, Cyclical & 184 & 169 \\
\hline Consumer, Non-cyclical & 135 & 249 \\
\hline Diversified & 47 & 7 \\
\hline Energy & 5 & 4 \\
\hline Financial & 233 & 180 \\
\hline Industrial & 274 & 379 \\
\hline Utilities & 35 & 12 \\
\hline Total & 1031 & 1109 \\
\hline
\end{tabular}


Table 2

Descriptive Statistics by Security Type and by Issuer

The table presents issuances and issuers' characteristics, distinguishing bond and sukuk issuances. All variables are in million USD with the exception of maturity (months), issue price (\%), coupon (\%) and financial ratios (\%). The stars denote the significance of t-test difference (mean) and Kruskall-Wallis median test between bond and $\operatorname{sukuk}(* \mathrm{p}<0.1, * * \mathrm{p}<0.05, * * * \mathrm{p}<0.01)$.

\begin{tabular}{|c|c|c|c|c|c|c|}
\hline & $\mathrm{N}$ & Mean & Median & Std. Dev. & Minimum & Maximum \\
\hline \multicolumn{7}{|l|}{ Issuances } \\
\hline \multicolumn{7}{|l|}{ Bond Issues } \\
\hline Amount & 1031 & $28.1^{* *}$ & $10.5^{\star \star \star}$ & 111 & 0.3 & 2200 \\
\hline Issue price & 418 & $98.3^{* * *}$ & $99.1^{* * *}$ & 6.9 & 13.9 & 100 \\
\hline Coupon & 1031 & 0.6 & 0 & 1.8 & 0.0 & 9 \\
\hline Maturity & 1031 & $0.8^{*}$ & $0.2^{*}$ & 1.9 & 0.0 & 18 \\
\hline \multicolumn{7}{|l|}{ Sukuk Issues } \\
\hline Amount & 1109 & $20.3^{\star *}$ & $7^{\star \star \star}$ & 56.9 & 0.5 & 854 \\
\hline Issue price & 588 & $99.2^{\star \star \star}$ & $99.5^{\star \star \star}$ & 1.3 & 74.3 & 102 \\
\hline Coupon & 1109 & 0.7 & 0 & 1.9 & 0.0 & 9 \\
\hline Maturity & 1109 & $1^{*}$ & $1.5^{\star}$ & 2.3 & 0.0 & 22 \\
\hline \multicolumn{7}{|l|}{ Issuers } \\
\hline \multicolumn{7}{|l|}{ Bond Issuers } \\
\hline Size & 223 & 687 & 170.6 & 1261.2 & 2.3 & 6499 \\
\hline Market-to-Book & 223 & 1.4 & 0.9 & 2.4 & -0.2 & 28 \\
\hline Leverage & 223 & $36.5^{\star \star}$ & 34 & 13.4 & 0.5 & 72 \\
\hline Current ratio & 223 & 1.7 & $1.3^{* *}$ & 1.3 & 0.0 & 12 \\
\hline Profitability & 223 & $9.1^{*}$ & 8 & 7.2 & -12.1 & 46 \\
\hline \multicolumn{7}{|l|}{ Sukuk Issuers } \\
\hline Size & 256 & 815.2 & 186.9 & 1808.8 & 4.1 & 15319 \\
\hline Market-to-Book & 256 & 1.3 & 0.9 & 1.0 & -0.1 & 7 \\
\hline Leverage & 256 & $33.9^{\star \star}$ & 32.2 & 13.2 & 1.6 & 80 \\
\hline Current ratio & 256 & 1.9 & $1.5^{\star *}$ & 1.4 & 0.2 & 12 \\
\hline Profitability & 256 & $8.1^{*}$ & 7.8 & 5.4 & -18.0 & 25 \\
\hline
\end{tabular}




\section{TABLE 3}

\section{Cumulative Abnormal Returns}

The table presents cumulative abnormal returns (CARs) around issuance announcement by issuance type. CARs are presented in percentage points. We use a market model with an estimation period lasting from -171 to -21 days before the issuance. We report cross-sectional $t\left(t_{C S}\right)$ and Boehmer, Masumeci, and Poulsen (1991)'s $t\left(t_{B M P}\right)$. For the percentage of negative observations, we perform a sign test. Stars denote significance $(* \mathrm{p}<0.1, * * \mathrm{p}<0.05$, $* * * \mathrm{p}<0.01)$.

\begin{tabular}{|c|c|c|c|c|c|c|c|}
\hline & $\mathrm{N}$ & CAR & tcs & $T>|\operatorname{tcs}|$ & $t_{\text {BMP }}$ & $T>\left|t_{B M P}\right|$ & Negative (\%) \\
\hline \multicolumn{8}{|l|}{ Window $[-1,1]$} \\
\hline Full Sample & 2140 & -0.19 & $-1.84^{*}$ & 0.07 & -0.38 & 0.71 & $54.22^{\star \star \star}$ \\
\hline During Ramadan & 207 & -0.37 & -0.88 & 0.38 & -0.68 & 0.5 & $56.99^{*}$ \\
\hline Outside of Ramadan & 1933 & -0.18 & -1.63 & 0.1 & -0.23 & 0.82 & $53.93^{\star \star \star}$ \\
\hline Sukuk & 1109 & -0.22 & -1.59 & 0.11 & -0.56 & 0.57 & $56.2^{* * *}$ \\
\hline Sukuk Ramadan & 111 & 0.23 & 0.41 & 0.69 & 0.01 & 0.99 & $62.04^{\star *}$ \\
\hline Sukuk Not Ramadan & 998 & -0.27 & $-1.93^{\star}$ & 0.05 & -0.58 & 0.56 & $55.54^{\star \star \star}$ \\
\hline Bond & 1031 & -0.16 & -1.03 & 0.3 & 0.13 & 0.9 & 52.02 \\
\hline Bond Ramadan & 96 & -1.07 & $-1.72^{*}$ & 0.09 & -1.17 & 0.25 & 50.59 \\
\hline Bond Not Ramadan & 935 & -0.07 & -0.43 & 0.66 & 0.41 & 0.68 & 52.16 \\
\hline
\end{tabular}


Table 4

Main Estimations

The table presents the regression results where cumulative abnormal returns is the dependent variable. The key explanatory variables are $S u k u k$ (which takes the value one if the issuance is a sukuk), Ramadan (equal to one if the issuance is during Ramadan), and their interaction Sukuk*Ramadan. The regression also includes issuance and issuer characteristics. Dummy variables for sectors and years are included but not reported. The variances are clustered at the issuer level. T-values are in parentheses and stars denote the significance $(* \mathrm{p}<0.1, * * \mathrm{p}<0.05$, $* * * \mathrm{p}<0.01)$.

\begin{tabular}{|c|c|c|c|c|c|}
\hline & (1) & (2) & (3) & (4) & (5) \\
\hline \multirow[t]{2}{*}{ Sukuk } & -0.015 & & -0.122 & -0.095 & -0.163 \\
\hline & $(-0.06)$ & & $(-0.59)$ & $(-0.46)$ & $(-0.72)$ \\
\hline \multirow[t]{2}{*}{ Ramadan } & & -0.199 & $-1.062^{*}$ & $-1.076^{\star}$ & $-1.061^{*}$ \\
\hline & & $(-0.51)$ & $(-1.80)$ & $(-1.84)$ & $(-1.80)$ \\
\hline \multirow[t]{2}{*}{ Sukuk×Ramadan } & & & $1.601^{* *}$ & $1.618^{\star *}$ & $1.606^{* *}$ \\
\hline & & & $(2.17)$ & $(2.21)$ & $(2.20)$ \\
\hline \multirow[t]{2}{*}{ Amount } & -0.023 & -0.022 & & 0.045 & -0.014 \\
\hline & $(-0.20)$ & $(-0.20)$ & & $(0.44)$ & $(-0.13)$ \\
\hline \multirow[t]{2}{*}{ Maturity } & -0.049 & -0.050 & & -0.054 & -0.053 \\
\hline & $(-1.49)$ & $(-1.48)$ & & $(-1.60)$ & $(-1.60)$ \\
\hline \multirow[t]{2}{*}{ Size } & 0.171 & 0.171 & & & 0.169 \\
\hline & $(1.63)$ & $(1.64)$ & & & $(1.61)$ \\
\hline \multirow[t]{2}{*}{ Market-to-Book } & 0.006 & 0.005 & & & 0.002 \\
\hline & $(0.11)$ & $(0.08)$ & & & $(0.03)$ \\
\hline \multirow[t]{2}{*}{ Leverage } & -0.010 & -0.010 & & & -0.010 \\
\hline & $(-0.75)$ & $(-0.75)$ & & & $(-0.75)$ \\
\hline \multirow[t]{2}{*}{ Current ratio } & $0.192^{* * *}$ & $0.191^{* * *}$ & & & $0.192^{* \star \star}$ \\
\hline & $(3.87)$ & (3.72) & & & (3.89) \\
\hline \multirow[t]{2}{*}{ Profitability } & 0.047 & 0.047 & & & 0.047 \\
\hline & $(1.43)$ & $(1.49)$ & & & $(1.44)$ \\
\hline \multirow[t]{2}{*}{ Constant } & -1.600 & -1.534 & -0.992 & -1.324 & -1.552 \\
\hline & $(-0.68)$ & $(-0.63)$ & $(-0.69)$ & $(-0.55)$ & $(-0.64)$ \\
\hline Sukuk+Ramadan+Ramadan $\times$ Sukuk & & & 0.416 & 0.447 & 0.381 \\
\hline $\mathrm{F}$ & & & 0.781 & 0.899 & 0.624 \\
\hline Ramadan+Ramadan $\times$ Sukuk & & & 0.539 & 0.542 & 0.545 \\
\hline $\mathrm{F}$ & & & 1.527 & 1.546 & 1.584 \\
\hline Sukuk+Ramadan×Sukuk & & & $1.479^{*}$ & $1.523^{\star *}$ & $1.442^{*}$ \\
\hline $\mathrm{F}$ & & & 3.649 & 3.958 & 3.905 \\
\hline $\mathrm{N}$ & 2140 & 2140 & 2140 & 2140 & 2140 \\
\hline $\mathrm{N}$ of issuers (clusters) & 133 & 133 & 133 & 133 & 133 \\
\hline $\mathrm{R}^{2}$ & 0.0140 & 0.0141 & 0.00843 & 0.00881 & 0.0164 \\
\hline $\mathrm{F}$ & $4.804^{* * *}$ & $4.392^{* * *}$ & $2.004^{\star * *}$ & $2.087^{\star * *}$ & $4.268^{\star \star \star}$ \\
\hline
\end{tabular}




\section{Table 5 \\ Unique and Multiple Issuers}

The table presents the regression results where cumulative abnormal returns is the dependent variable. The sample is divided between unique issuers (firms which have only issued one type of security in the five previous years) and multiple issuers. Dummy variables for sectors and years are included but not reported. The variances are clustered at the issuer level. T-values are in parentheses and stars denote the significance $\left({ }^{*} \mathrm{p}<0.1,{ }^{*} \mathrm{p}<0.05\right.$, $* * * \mathrm{p}<0.01)$.

\begin{tabular}{|c|c|c|c|c|c|c|}
\hline & \multicolumn{3}{|c|}{ Unique Issuers } & \multicolumn{3}{|c|}{ Multiple Issuers } \\
\hline & (1) & (2) & (3) & (1) & (2) & (3) \\
\hline \multirow[t]{2}{*}{ Sukuk } & -0.035 & -0.027 & 0.027 & -1.157 & -1.005 & -0.987 \\
\hline & $(-0.15)$ & $(-0.12)$ & $(0.11)$ & $(-1.19)$ & $(-1.11)$ & $(-1.03)$ \\
\hline \multirow[t]{2}{*}{ Ramadan } & $-1.604^{\star *}$ & $-1.596^{\star \star}$ & $-1.623^{\star \star}$ & -0.173 & -0.332 & -0.260 \\
\hline & $(-2.15)$ & $(-2.16)$ & $(-2.14)$ & $(-0.15)$ & $(-0.30)$ & $(-0.21)$ \\
\hline \multirow[t]{2}{*}{ Sukuk×Ramadan } & $2.065^{\star}$ & $2.052^{*}$ & $2.087^{*}$ & 1.342 & 1.479 & 1.404 \\
\hline & $(1.87)$ & $(1.87)$ & $(1.88)$ & $(1.05)$ & $(1.16)$ & $(1.05)$ \\
\hline \multirow[t]{2}{*}{ Amount } & & -0.064 & -0.141 & & 0.340 & 0.359 \\
\hline & & $(-0.60)$ & $(-1.29)$ & & $(1.10)$ & $(1.17)$ \\
\hline \multirow[t]{2}{*}{ Maturity } & & 0.004 & 0.005 & & -0.107 & -0.145 \\
\hline & & $(0.08)$ & $(0.08)$ & & $(-0.79)$ & $(-0.94)$ \\
\hline \multirow[t]{2}{*}{ Size } & & & $0.201^{*}$ & & & 0.359 \\
\hline & & & (1.91) & & & $(0.95)$ \\
\hline \multirow[t]{2}{*}{ Market-to-Book } & & & 0.030 & & & -0.319 \\
\hline & & & $(0.52)$ & & & $(-1.34)$ \\
\hline \multirow[t]{2}{*}{ Leverage } & & & -0.011 & & & 0.0175 \\
\hline & & & $(-0.69)$ & & & $(0.69)$ \\
\hline \multirow[t]{2}{*}{ Current ratio } & & & $0.202^{\star *}$ & & & 0.107 \\
\hline & & & $(2.52)$ & & & $(0.89)$ \\
\hline \multirow[t]{2}{*}{ Profitability } & & & $0.075^{\star \star}$ & & & -0.033 \\
\hline & & & $(2.02)$ & & & $(-0.56)$ \\
\hline \multirow[t]{2}{*}{ Constant } & -0.488 & 0.615 & -1.369 & -1.642 & -7.677 & -9.959 \\
\hline & $(-0.84)$ & $(0.33)$ & $(-0.74)$ & $(-1.20)$ & $(-1.30)$ & $(-1.67)$ \\
\hline Sukuk+Ramadan+Ramadan $\times$ Sukuk & 0.426 & 0.429 & 0.491 & 0.0114 & 0.143 & 0.157 \\
\hline $\mathrm{F}$ & 0.248 & 0.252 & 0.309 & 0.001 & 0.0215 & 0.0261 \\
\hline Ramadan+Ramadan $\times$ Sukuk & 0.461 & 0.456 & 0.464 & $1.169^{\star \star}$ & $1.147^{*}$ & $1.144^{\star \star}$ \\
\hline $\mathrm{F}$ & 0.325 & 0.316 & 0.336 & 4.233 & 4.073 & 4.298 \\
\hline Sukuk+Ramadan $\times$ Sukuk & $2.030^{*}$ & $2.025^{*}$ & $2.114^{*}$ & 0.184 & 0.475 & 0.417 \\
\hline $\mathrm{F}$ & 3.031 & 3.037 & 3.366 & 0.150 & 0.528 & 0.319 \\
\hline N & 1426 & 1426 & 1426 & 467 & 467 & 467 \\
\hline $\mathrm{N}$ of issuers (clusters) & 105 & 105 & 105 & 33 & 33 & 33 \\
\hline $\mathrm{R}^{2}$ & 0.0140 & 0.0142 & 0.0272 & 0.0399 & 0.0428 & 0.0482 \\
\hline
\end{tabular}




\section{Table 6}

\section{Robustness Checks}

The table presents four robustness regressions for the Ramadan specification. Column 1 uses an alternative window, $[-1,0]$. Column 2 presents an alternative computation of expected returns, using a modified model (CAR Modified), with a [-1,1] window. Column 3 uses an alternative index to compute CAR, FBM100 (CAR FBM100). Last, column 4 tests the influence of the crisis period with a dummy variable Crisis equal to one if the year is 2008 or 2009 and zero otherwise. Dummy variables for sectors and years are included but not reported. The variances are clustered at the issuer level. T-values are in parentheses and stars denote the significance $(* \mathrm{p}<0.1$, $* * \mathrm{p}<0.05, * * * \mathrm{p}<0.01)$.

\begin{tabular}{|c|c|c|c|c|}
\hline & $\begin{array}{c}(1) \\
\text { CAR[-1,0] }\end{array}$ & $\begin{array}{c}(2) \\
\text { CAR Modified }\end{array}$ & $\begin{array}{c}(3) \\
\text { CAR FBM100 }\end{array}$ & $\begin{array}{c}(4) \\
\text { Crisis }\end{array}$ \\
\hline \multirow[t]{2}{*}{ Sukuk } & -0.197 & -0.313 & -0.154 & -0.163 \\
\hline & $(-0.82)$ & $(-1.63)$ & $(-0.67)$ & $(-0.72)$ \\
\hline \multirow[t]{2}{*}{ Ramadan } & -0.954 & -0.693 & $-1.085^{\star}$ & $-1.061^{*}$ \\
\hline & $(-1.54)$ & $(-1.54)$ & $(-1.84)$ & $(-1.80)$ \\
\hline \multirow[t]{2}{*}{ SukukxRamadan } & $1.467^{*}$ & 0.903 & $1.592^{\star *}$ & $1.614^{\star \star}$ \\
\hline & $(1.88)$ & $(1.60)$ & $(2.17)$ & $(2.17)$ \\
\hline \multirow[t]{2}{*}{ Crisis } & & & & -0.204 \\
\hline & & & & $(-0.16)$ \\
\hline \multirow[t]{2}{*}{ Sukuk $\times$ Ramadan $\times$ Crisis } & & & & -0.0485 \\
\hline & & & & $(-0.05)$ \\
\hline \multirow[t]{2}{*}{ Amount } & -0.072 & 0.112 & -0.020 & -0.0142 \\
\hline & $(-0.80)$ & $(1.61)$ & $(-0.19)$ & $(-0.13)$ \\
\hline \multirow[t]{2}{*}{ Maturity } & -0.0346 & 0.002 & -0.052 & -0.0525 \\
\hline & $(-1.13)$ & $(0.04)$ & $(-1.60)$ & $(-1.60)$ \\
\hline \multirow[t]{2}{*}{ Size } & 0.126 & 0.061 & 0.172 & 0.169 \\
\hline & (1.35) & $(0.59)$ & (1.63) & $(1.62)$ \\
\hline \multirow[t]{2}{*}{ Market-to-Book } & 0.040 & 0.009 & 0.002 & 0.00175 \\
\hline & $(0.66)$ & $(0.21)$ & $(0.03)$ & $(0.03)$ \\
\hline \multirow[t]{2}{*}{ Leverage } & -0.0140 & 0.007 & -0.009 & -0.00994 \\
\hline & $(-1.15)$ & $(0.87)$ & $(-0.71)$ & $(-0.75)$ \\
\hline \multirow[t]{2}{*}{ Current ratio } & $0.125^{\star * *}$ & $0.084^{\star *}$ & $0.189^{\star \star \star}$ & $0.192^{* * *}$ \\
\hline & $(2.96)$ & $(2.02)$ & $(3.83)$ & (3.88) \\
\hline \multirow[t]{2}{*}{ Profitability } & $0.055^{* *}$ & 0.011 & 0.048 & 0.0470 \\
\hline & $(2.04)$ & $(0.51)$ & $(1.48)$ & $(1.44)$ \\
\hline \multirow[t]{2}{*}{ Constant } & -1.029 & $-3.475^{*}$ & -1.736 & -1.548 \\
\hline & $(-0.43)$ & $(-1.80)$ & $(-0.71)$ & $(-0.64)$ \\
\hline N & 2140 & 2140 & 2140 & 2140 \\
\hline $\mathrm{N}$ of issuers (clusters) & 133 & 133 & 133 & 133 \\
\hline $\mathrm{R}^{2}$ & 0.0102 & 0.0193 & 0.0166 & 0.0200 \\
\hline $\mathrm{F}$ & $4.388^{\star * *}$ & $3.133^{* * *}$ & $4.206^{* * *}$ & $4.438^{* * *}$ \\
\hline
\end{tabular}




\section{REFERENCES}

Al-Khazali, O., 2014, Revisiting Fast Profit Investor Sentiment and Stock Returns During Ramadan. International Review of Financial Analysis 33, 158-1709.

Ariel, R.A., 1987, A Monthly Effect in Stock Returns, Journal of Financial Economics 18, 1, 161-174.

Baele, L., Farooq, M., Ongena, S., 2014, Of Religion and Redemption: Evidence from Default on Islamic Loans, Journal of Banking and Finance 44, 6, 141-159.

Bailey, W., Kumar, A., and Ng, D., 2011, Behavioral Biases of Mutual Fund Investors, Journal of Financial Economics 102, 1-27.

Barberis, B., Thaler, R., 2003, A Survey of Behavioral Finance. In: G.M. Constantinides \& M. Harris \& R. M. Stulz (ed.), Handbook of the Economics of Finance, vol. 1, chapter 18, 1053-1128, Elsevier.

Ben-David, I., and Hirshleifer, D., 2012, Are Investors Really Reluctant to Realize Their Losses? Trading Responses to Past Returns and the Disposition Effect, Review of Financial Studies 25, 2485-2532.

Bialkowski, J., Etebari, A., Wisniewski, T., 2012, Fast Profits: Investor Sentiment and Stock Returns during Ramadan, Journal of Banking and Finance 36, 835-845.

Bialkowski, J., Bohl, J., Kaufmann, P., Wisniewski, T., 2013, Do Mutual Fund Managers Exploit the Ramadan Anomaly? Evidence from Turkey, Emerging Markets Review 15, 211-232.

Boehmer, E., Masumeci, J., Poulsen, A., 1991, Event-Study Methodology under Conditions of Event-Induced Variance, Journal of Financial Economics 30, 253-272.

Brown, S.J., Warner, J.B., 1985, Using Daily Stock Returns: The Case of Event Studies, Journal of Financial Economics 14, 1, 3-31.

Bursztyn, L., Fiorin, S., Gottlieb, D., and Kanz M., 2015, Moral Incentives: Experimental Evidence from Repayments of an Islamic Credit Card, Working Paper, National Bureau of Economic Research.

Cakir, S. and F. Raei, 2007, Sukuk vs. Eurobonds: Is There a Difference in Value-at-Risk?, International Monetary Fund Working Paper WP/07/237. 
Campante F., Yanagizawa-Drott, D., 2013, Does Religion Affect Economic Growth and Happiness? Evidence from Ramadan, NBER Working Paper 19768.

Coval, Joshua D., and Shumway T., 2005, Do Behavioral Biases Affect Prices?, The Journal of Finance 60, 1-34.

Daniel, Kent D., Hirshleifer D., and Subrahmanyam A., 1998, Investor Psychology and Security Market Under- and Overreactions, The Journal of Finance 53, 1839-1885.

Daniel, Kent D., Hirshleifer, D., and Subrahmanyam A., 2001, Overconfidence, Arbitrage, and Equilibrium Asset Pricing, The Journal of Finance 56, 921-965.

Daniel, K., Hirshleifer, D., Teoh, S.H., 2002, Investor Psychology in Capital Markets: Evidence and Policy Implications, Journal of Monetary Economics 49, 139-209.

Fama, Eugene F., 1998, Market Efficiency, Long-term Returns, and Behavioral Finance, Journal of Financial Economics 49, 283-306.

Feng, L., and Seasholes, Mark S., 2005, Do Investor Sophistication and Trading Experience Eliminate Behavioral Biases in Financial Markets?, Review of Finance 9, 305-351.

Godlewski, C., Turk-Ariss, R., Weill, L., 2013, Sukuk vs. Conventional Bonds: A Stock Market Perspective, Journal of Comparative Economics 41, 3, 745-761.

Godlewski, C., Turk-Ariss, R., Weill, L., 2016, Do the Type of Sukuk and Choice of Shari'a Scholar Matter?, Journal of Economic Behavior \& Organization, 132, 63-76.

Guiso, L., Sapienza, P., and Zingales, P., 2003, People's Opium?, Religion and Economic Attitudes, Journal of Monetary Economics 50, 225-282.

Gultekin, M.N., Gultekin, N.B., 1983, Stock Market Seasonality: International Evidence, Journal of Financial Economics 12, 4, 469-481.

Halari, A., Tantisantiwong, N., Power, D., Helliar, C., 2015, Islamic Calendar Anomalies: Evidence from Pakistani Firm-Level Data, Quarterly Review of Economics and Finance 58, 64-73.

Hilary, G., Hui, K.W., 2009, Does Religion Matter in Corporate Decision Making in America?, Journal of Financial Economics 93, 455-473. 
Hussain, M, Shahmoradi, A. and Turk-Ariss, R., 2015, An Overview of Islamic Finance, International Monetary Fund Working Paper 15/120, Washington DC: International Monetary Fund.

International Monetary Fund, 2015, Islamic Finance: Opportunities, Challenges, and Policy Options, Staff Discussion Note 15/05, Washington DC: International Monetary Fund.

Jaffe, J., Westerfield, R., 1985, The Weekend Effect in Common Stock Market Returns: The International Evidence, Journal of Finance 40, 2, 433-454.

KFUPM, 2016, Islamic Finance Bulletin, King Fahd University of Petroleum and Minerals.

Kothari, S. P., Lewellen, J., and Warner, Jerold B., 2006. Stock Returns, Aggregate Earnings Surprises, and Behavioral Finance, Journal of Financial Economics 79, 537-568.

Kumar, A., 2009. Hard-to-Value Stocks, Behavioral Biases, and Informed Trading, Journal of Financial and Quantitative Analysis 44, 1375-1401.

Kumar, A., Page, J.K., Spalt, O.G., 2011, Religious Beliefs, Gambling Attitudes, and Financial Market Outcomes, Journal of Financial Economics 102, 671-708.

Leiper, J. B., and A. M. Molla, 2003. Effects on Health of Fluid Restriction during Fasting in Ramadan, European Journal of Clinical Nutrition 57, S30-S38.

Loughran, T., Schultz, P., 2004, Weather, Stock Returns, and the Impact of Localized Trading Behavior, Journal of Financial and Quantitative Analysis 39, 343-364.

MacKinlay, A., 1997, Event Studies in Economics and Finance, Journal of Economic Literature 35, 1, 13-39.

Miller, N.D., Challoner, J., Atta, A., 2007, UK Welcomes the Sukuk, International Financial Law Review 26, 5, 24-25.

Pantzalis, C., Urcar, E., 2014, Religious Holidays, Investor Distraction, and Earnings Announcement Effects, Journal of Banking and Finance 47, 102-117.

Renneboog, L., Spaenjers, C., 2012, Religion, Economic Attitudes, and Household Finance, Oxford Economic Papers 64, 103-127.

Seyyed, F., Abraham, A., Al-Hajji, M., 2005, Seasonality in Stock Returns and Volatility: the Ramadan Effect, Research in International Business and Finance 19, 3, 374-383. 
Stulz, René M., and Williamson, R., 2003, Culture, Openness, and Finance, Journal of Financial Economics 70, 313-349.

Tendulkar, R., 2015, Corporate Bond Markets: An Emerging Markets Perspective, Staff Working Paper of the IOSCO Research Department.

TheCityUK, 2015, Islamic Finance Report 2015, Financial Market Series, TheCityUK, London.

Turk-Ariss, R., Rezvanian, R., Mehdian, S., 2011, Calendar Anomalies in the Gulf Cooperation Council Stock Markets, Emerging Markets Review 12, 293-307.

Wilson, R., 2008, Innovation in the Structuring of Islamic Sukuk Securities, Humanomics 24, 170-181.

Zhang, X. F., 2006, Information Uncertainty and Stock Returns, The Journal of Finance 61, $105-137$. 